\title{
Effects of magnesium deficiency on reproduction in the white rat
}

\author{
BY C. ANDRIEUX-DOMONT AND LE VAN HUNG \\ Laboratory of Nutrition Physiology, \\ Sorbonne, I rue Victor Cousin, Paris Ve \\ (Received 6 March 1972-Accepted 28 September 1972)
}

\footnotetext{
I. Groups of rats were maintained from weaning on magnesium-deficient ( $3 \circ \mathrm{mg} \mathrm{Mg} / \mathrm{kg}$ ) and control $(460 \mathrm{mg} \mathrm{Mg} / \mathrm{kg}$ ) diets.

2. $\mathrm{Mg}$ deficiency for a period of more than 3 months resulted in sterility of both males and females.

3. A Mg deficiency of less than 3 months caused abortions or resorptions in utero of foetuses in pregnant females before other physical signs appeared.

4. Mg deficiency during lactation rendered the survival of young rats uncertain. The mother rat died of exhaustion if she did not devour her litter.

5. The growth of surviving young rats born of $\mathrm{Mg}$-deficient mothers was noticeably retarded when they were nursed by mothers receiving the $\mathrm{Mg}$-deficient diet.
}

It has been known for many years that pregnancy and lactation both require the contribution of numerous substances held in reserve, notably mineral salts. Jacquot (1960) showed that during early pregnancy the female rat stores the materials necessary for lactation. What happens when these indispensable elements are no longer furnished? Various authors have determined that a deficiency in calcium leads to premature births and a decrease in the amounts of $\mathrm{Ca}$ and phosphorus in the bone (Hart, McCollum, Steenbock \& Humphrey, I9II; Toverad \& Toverad, I93I). Bodansky \& Duff (I94I) showed that foetal growth in the rat depended on the amounts of $\mathrm{Ca}$ and $\mathrm{P}$ in the diet, and that iron, manganese and copper deficiencies gave rise respectively to anaemia, stunted limbs and degeneration of the central nervous system in the newborn rats.

Le Roy (I926) asserted that magnesium was essential to reproduction in the mouse, and Tufts $\&$ Greenberg (1937-8) sought to determine the minimum level of food $\mathrm{Mg}$ that would permit normal reproduction in female rats. Sell, Cox \& Hajj (r966) further showed that when given less than $30 \mu \mathrm{g} \mathrm{Mg} / \mathrm{d}$ per bird, hens remained sterile. Aikawa (1960) measured the Mg flow through the placenta of the rabbit and concluded that the foetus received a large quantity of $\mathrm{Mg}$ from the reserves in the mother's bone. Lactation has been studied in several kinds of mammals, especially ruminants, which show signs of tetanus due to $\mathrm{Mg}$ deficiency (L'Estrange \& Axford, I964; Lowrey \& Grunes, I968).

The following study was undertaken to examine the effects of $\mathrm{Mg}$ deficiency on reproduction in the rat, in particular on fertility, gestation and lactation - three periods during which this metal has proved indispensable. 
Table I. Composition of the diets ( $\mathrm{g} / \mathrm{kg}$ ) (From Le Breton, ig6o)

Control (magnesium content $460 \mathrm{mg} / \mathrm{kg}$ )

\begin{tabular}{lr} 
Devitaminized casein & 230 \\
Sucrose & 570 \\
Lard & 100 \\
Salt mixture* & 50 \\
Vitamin mixturet & 25 \\
\multicolumn{1}{l}{ Mg-deficient (MIg content, $30 \mathrm{mg} / \mathrm{kg}$ ) }
\end{tabular}

The composition of this diet was similar to that of the control diet except that the content of $\mathrm{Mg}$ sulphate in the salt mixture was reduced and replaced by an equal amount of sucrose.

* Containing $(\mathrm{g} / \mathrm{kg})$ : sodium chloride 95 ; dipotassium phosphate 290 ; monosodium phosphate 140 ; monocalcium phosphate 290 ; magnesium sulphate $x 00$; ferric lactate 25 ; potassium iodide 0.85 ; potassium alum 0.1 ; manganese sulphate 0.075 ; sodium fiuoride 0.03 .

$\dagger$ Providing (per $\mathrm{kg}$ diet): menaphthone, $5 \mathrm{mg}$; retinyl acetate, $2 \mathrm{mg}$; cholecalciferol, $250 \mu \mathrm{g}$; biotin, I mg; vitamin $\mathrm{E}$, $\alpha$-tocopherol equivalent, $300 \mathrm{mg}$; cyanocobalamin, $20 \mu \mathrm{g}$; thiamin $20 \mathrm{mg}$; riboflavin, $20 \mathrm{mg}$; pyridoxine, $20 \mathrm{mg}$; nicotinic acid, $25 \mathrm{mg}$; pantothenic acid (as calcium salt), $50 \mathrm{mg}$; pteroylmonoglutamic acid, $2 \mathrm{mg} ;$ myo-inositol, $850 \mathrm{mg}$; choline, $2 \mathrm{~g}$; made up in agar.

\section{EXPERIMENTAL}

Wistar rats were used, the females being 3 months old, an age which, according to Hafez (1963), corresponds to the period of maximum fertility. Two different diets were prepared: one, the control, was complete and balanced with a $\mathrm{Mg}$ content of $460 \mathrm{mg} / \mathrm{kg}$; the second diet was deficient in $\mathrm{Mg}$, its $\mathrm{Mg}$ content being only $30 \mathrm{mg} / \mathrm{kg}$. Both diets were devised by Le Breton (1960); their compositions are given in Table 1. The animals were fed $a d l i b$, and they drank demineralized water. In one group, forty-five females and ten males were maintained on the control diet from weaning until the age of 3 months; in a second group, forty females and ten males were maintained on the diet deficient in $\mathrm{Mg}$ for $42 \mathrm{~d}$. Twenty-five control females were mated with. control males, and the other twenty control females were mated with males on the Mg-deficient diet. Twenty females on the Mg-deficient diet were mated with control males and the remaining twenty females were mated with males on the $\mathrm{Mg}$-deficient diet: four groups of animals were thus obtained.

During the mating period, each mating couple was maintained on the $\mathrm{Mg}$-deficient diet where one animal in the couple was maintained on the $\mathrm{Mg}$-deficient diet before mating.

Oestrus was ascertained by vaginal smear analysis and the beginning of gestation was verified by the presence of sperms in the vagina.

After $5 \mathrm{~d}$ of mating, males were separated from females and each group of females was further subdivided into two; half were given the $\mathrm{Mg}$-deficient diet and half were given the control diet for the remainder of the gestation period. Eight groups of female rats were thus obtained including one control group of fifteen animals. The females were isolated in individual cages $8 \mathrm{~d}$ before the end of pregnancy. Some females rats were killed during gestation to study the foetus.

The newborn rats were numbered and weighed and, $5 \mathrm{~d}$ after birth, the amount of $\mathrm{Mg}$ in the liver of some rats was determined by flame spectrometry (MacIntyre \& Davidsson, 1958). During lactation, each group of females was further subdivided, 
Table 2. Effects of magnesium content of the diet on reproduction and lactation in normal female rats mated with normal males given the control diet (diet $T$ ), or with males given a Mg-deficient diet (diet $T M g$ ) for 6 weeks; half of the females were given diet $T$ and half were given the $T M g$ diet after mating and throughout gestation and lactation

Diet after mating
Cross and diet before mating ...
No. of matings
No. of impregnations
No. of litters
No. of abortions
No. of offspring
No. of offspring/litter
Wt. of newborn rats (g)
No. of offspring surviving to 3 rd day
Offspring devoured by their mother
Mg content of liver of offspring in
their 5 th day ( $\mu$ gig)*
No. of females surviving at the
beginning of lactation

Diet during lactation

No. of females at the beginning of lactation

No. of offspring at the beginning of lactation

No. of females surviving at weaning

No. of offspring surviving at 3 weeks

$\overbrace{\mathrm{T} \times j \mathrm{~T}}^{\text {Dict } \mathrm{T}(460 \mathrm{mg} \mathrm{Mg} / \mathrm{kg})} \underbrace{\mathrm{m}}_{q \mathrm{~T} \times \delta \mathrm{TMg}}$

Reproduction

\begin{tabular}{|c|c|c|c|}
\hline \multicolumn{4}{|c|}{ Reproduction } \\
\hline$x_{5}$ & 10 & 10 & 10 \\
\hline I I & 6 & 7 & 6 \\
\hline I I & 6 & 6 & 5 \\
\hline 0 & $\circ$ & $\mathbf{I}$ & $I$ \\
\hline$\frac{95}{8 \cdot 6+\mathrm{I} \cdot 8}$ & $33.5+2 \cdot 2$ & 29 & $\begin{array}{l}25 \\
5 \cdot 0+0.6\end{array}$ \\
\hline $5.4 \pm 0.4$ & $5.9 \pm 0.6$ & $\begin{array}{l}49 \pm 1.2 \\
5.4 \pm 0.6\end{array}$ & $5.6 \pm 0.5$ \\
\hline 95 & 33 & 15 & I 3 \\
\hline 0 & 0 & 14 & I 2 \\
\hline $220 \pm 16$ & $22 \mathrm{I} \pm \mathrm{x} 5$ & $213 \pm 12$ & $270 \pm I I$ \\
\hline$\downarrow_{\text {Lact }}^{\text {I I }}$ & 6 & $\downarrow$ & 4 \\
\hline$\overbrace{\mathrm{T}}^{\mathrm{TMg}}$ & $\stackrel{\mathrm{T}}{\mathrm{TMg}}$ & $\overbrace{\mathrm{T}}^{\mathrm{TM} g}$ & $\overbrace{\mathrm{T}}^{\mathrm{TMg}}$ \\
\hline 65 & 33 & 2 & 3 \\
\hline $49 \quad 4 I$ & I $5 \quad$ I3 & 5 & 6 \\
\hline 64 & 2 & I & $\mathbf{I}$ \\
\hline $49 \quad 20$ & 156 & 4 & 2 \\
\hline
\end{tabular}

* Mean values with their standard errors.

Diet TMg (3० mg Mg/kg)

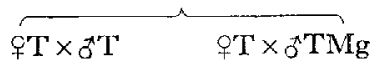


Table 3. Effects of the magnesium content of the diet on reproduction and lactation in female rats given a Mg-deficient diet (diet TMg) for 6 weeks and mated with normal males given the control diet (diet T) or with males given diet TMg for 6 weeks; half of the females were given diet $T$ and half were given diet TMg after mating and throughout gestation and lactation

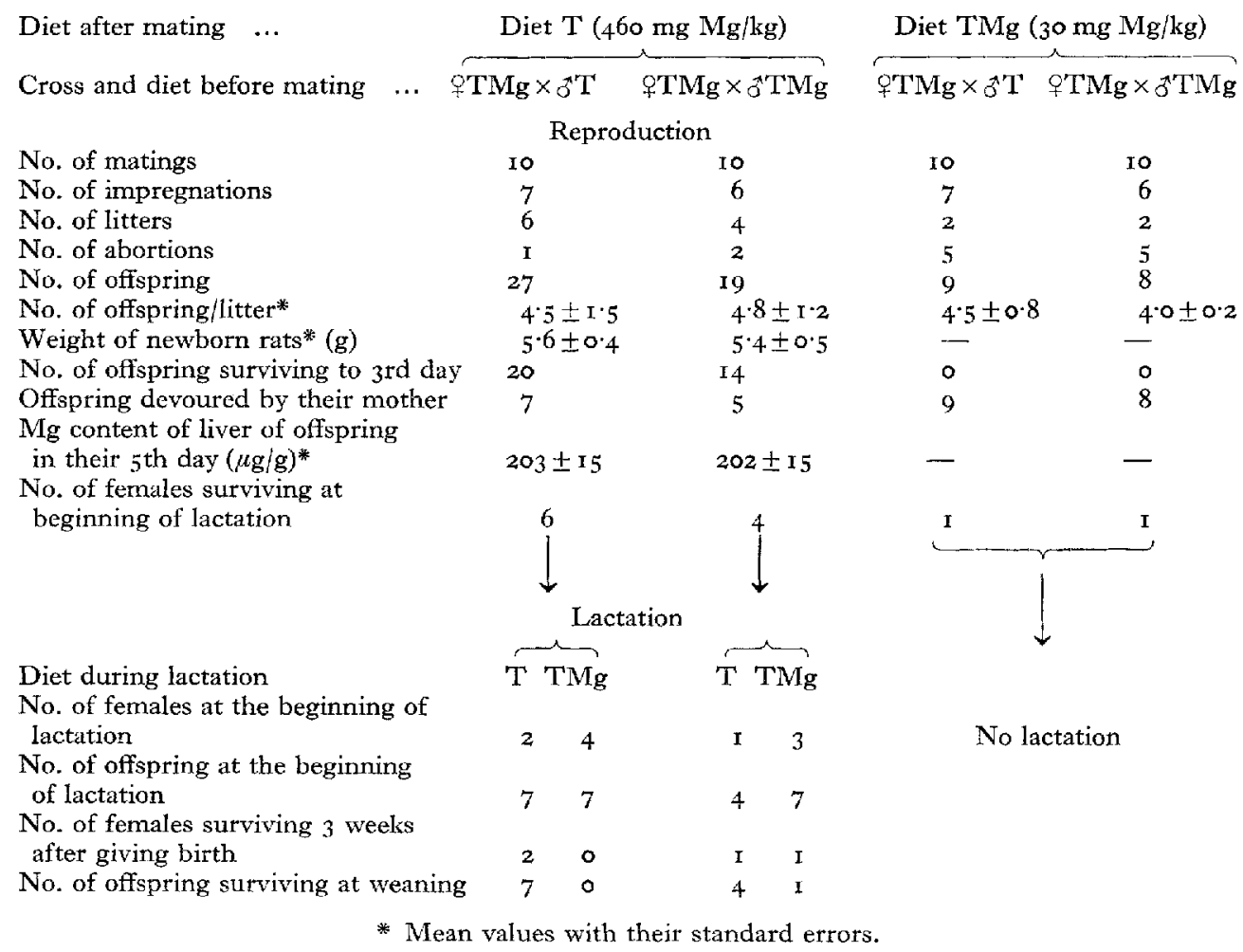

the accepted statistical averages. Mating with $\mathrm{Mg}$-deficient males produced a pregnancy rate of only $60 \%$.

The females that were given the control diet during gestation gave birth to viable young; but those that were mated with Mg-deficient males, produced smaller litters, four to five young instead of eight or more. When these same females were given the $\mathrm{Mg}$-deficient diet during lactation they either died at the end of this period, or killed their offspring without, however, devouring them. When females were given the Mg-deficient diet during gestation, the percentage of live births remained the same, but about $50 \%$ of the litter was either abandoned or devoured by the mother, and when the $\mathrm{Mg}$-deficient diet was continued, the female rats died during, or at the end, of lactation.

The concentration of liver $\mathrm{Mg}$ in young rats ( $5 \mathrm{~d}$ old), was slightly lower in those born of mothers who were given the $\mathrm{Mg}$-deficient diet during gestation. 


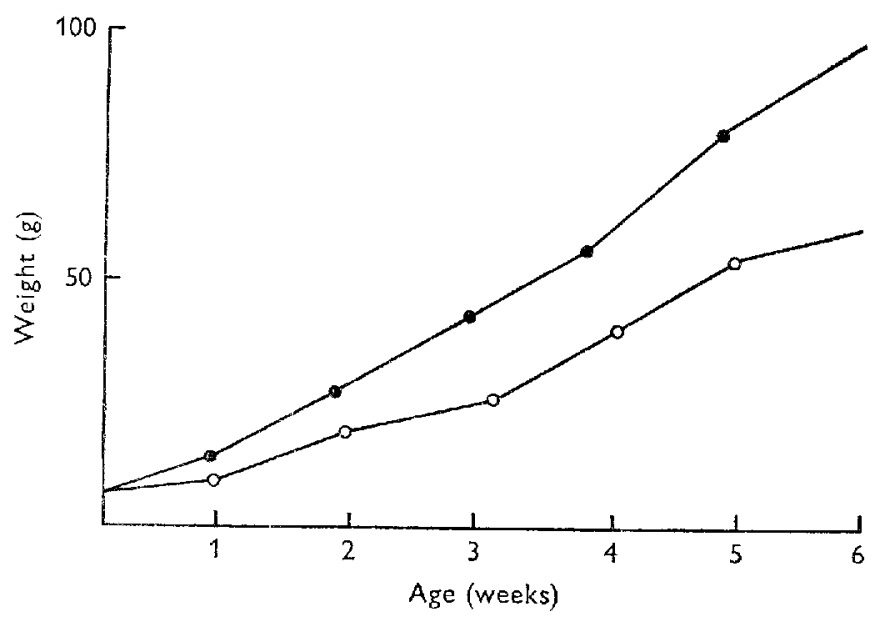

Fig. I. Rate of weight gain of newborn rats (produced from mating control male rats with female rats which received the control diet during gestation) nursed by females given the control diet (-), or nursed by females given a magnesium-deficient diet $(0-O)$, during the lactation period.

\section{Mating of Mg-deficient females with normal oring-deficient males (Table 3)}

Vaginal smear analysis showed that there was a $60-70 \%$ pregnancy rate, but the pregnancies reached full term only when the Mg-deficient diet was withdrawn immediately after separation of the males and the females. Nevertheless, litters were smaller, four to five young rats, and $20 \%$ of the litters were devoured by the mother. The weights of the newborn rats were normal, but the $\mathrm{Mg}$ concentration in their livers was slightly lower than in those born in the control group $(200 \mu \mathrm{g} / \mathrm{g}$ fresh liver compared to $220 \mu \mathrm{g} / \mathrm{g}$ for the controls).

On the other hand, when Mg-deficient females were maintained on the $\mathrm{Mg}$ deficient diet after mating, numerous abortions were observed and all the newborn rats either were abandoned by their mother and died, or were devoured by her. Because of the large number of abortions and the reduced size of the litters, it was decided to kill several additional females to study the contents of the uterus. It was observed that gestation began normally at the opening of the uterus and the number of implantations was similar to the normal figure obtained with rats on the control diet. Towards the end of pregnancy, however, the number of foetuses was reduced, although the number of implantation sites remained the same. The condition of the foetuses showed considerable variation: some were fully developed, but others had stopped developing or were already partly resorbed.

\section{Effects of $M g$ deficiency on lactation}

It has been noted that the females given the Mg-deficient diet before and during gestation devoured their young; the females given the Mg-deficient diet before mating and then placed on the normal diet during gestation had a normal though smaller litter, and they suckled their young until weaning. However, when females in the latter group were placed again on the $\mathrm{Mg}$-deficient diet at the beginning of 
lactation, two of them died at the beginning of this period and all died before weaning. By then, they weighed much less than normal females. At autopsy their kidneys were seen to be injured, appearing nephritic; the $\mathrm{Mg}$ concentration in the kidneys about $16 \mu \mathrm{g} / \mathrm{g}$ fresh tissue in the rats given the control dict - reached $18 \mu \mathrm{g} / \mathrm{g}$. This increase in concentration of $\mathrm{Mg}$ in the kidneys is one of the characteristics of $\mathrm{Mg}$ deficiency in the adult rat (Andrieux-Domont \& Le Van Hung, 1969). In contrast we observed that the $\mathrm{Mg}$ concentration of the liver in female rats given the Mgdeficient diet decreased.

When the females in the control group were given the Mg-deficient diet during pregnancy and lactation, they died before the pups were weaned; but females which were replaced on the control diet after giving birth produced milk normally and the gain in body-weight of the litters was satisfactory - growth was retarded when the newborn rats were nursed by females receiving the $M g$-deficient diet (Fig. I).

\section{DISCUSSION}

It is evident that $\mathrm{Mg}$ deficiency has repercussions on reproduction. The males become sterile only when they are kept on a $\mathrm{Mg}$-deficient diet for a long period: between $\mathrm{I}$ and 6 weeks the number of successful matings, as verified by the presence of sperms in vaginal smears, is normal. Although no abortions were seen in females of the control group mated with $\mathrm{Mg}$-deficient males, the number of young in each litter was nevertheless smaller, and though the foetuses showed no malformations, it was not possible to conclude, therefore, that their development was normal and that they were all viable. It was shown earlier, that the $\mathrm{Mg}$ concentration in the tissues of adult animals given the Mg-deficient diet decreased noticeably. It is not unlikely, therefore, that the testicles of rats given the $\mathrm{Mg}$ deficient diet have a smaller $\mathrm{Mg}$ content and that in consequence spermatogenesis becomes abnormal.

In females, it was necessary to distinguish between gestation and lactation - two periods during which there is a great loss of $\mathrm{Mg}$ (Coumel, 1967 ; Greenwald, Dubin $\&$ Cardon, 1963). In females given the $\mathrm{Mg}$-deficient diet before gestation, and the control diet during gestation, the abortion rate was only $10 \%$. When they were maintained on the $\mathrm{Mg}$-deficient diet, however, the abortion rate was $50 \%$. In normal females placed on the Mg-deficient diet during gestation, the abortion rate was the same as that of the control group. These findings agree with those of Doiseau (1954) and Dumont \& Bernard (1966), emphasizing the efficient action of $\mathrm{Mg}$ salts in human cases where there is a risk of abortion. In addition, Chein \& Kelly (1967) demonstrated that the sensitivity of the uterine muscle to oxytocin depended on the concentration of $\mathrm{Mg}$ in the serum.

It is important to note, however, that the signs of deficiency as such are not immediately obvious in the pregnant rat. The different stages of $\mathrm{Mg}$ deficiency in the adult rat were noted in a previous article (Andrieux-Domont \& Le Van Hung, 1971): the first cutaneous symptoms are vasodilatation and a red secretion staining first the muzzle, then the neck and finally the entire fur. This secretion was identified as porphyrin by Raoul \& Marnay (1945). These visible symptoms were not observed 
in the pregnant female rats: but at autopsy, the kidneys were seen to be injured. In the kidneys, the concentration of $\mathrm{Mg}$ had risen by $2 \mu \mathrm{g} / \mathrm{g}$ fresh tissue, and it had fallen by the same amount in the liver. Distinction should therefore be made between the sudden increase in the need for $\mathrm{Mg}$ during gestation and lactation, and the chronic insufficiency which ensues as a result of a prolonged period on a Mg-deficient diet.

Administration of the $\mathrm{Mg}$-deficient diet during gestation did not appear to have a direct effect on the foetus and on the newborn rat; their survival depended on the condition of the mother. However, in contrast to the results of Tufts \& Greenberg (I937-8), who did not report any difference in the Mg content of newborn rats, our experiment showed that the concentration of $\mathrm{Mg}$ had decreased in the livers of young rats born of mothers placed on the Mg-deficient diet. A decrease in the concentration of serum $\mathrm{Mg}$ in the newborn human baby may cause convulsions (Salet, Polonowski, De Gouyon, Pean, Melekian \& Fournet, I966; Fricdman, Hatcher \& Watson, 1967 ; Paunier, Radd \& Sang Whay Kooh, r968). Wang, Wang, Khairallah \& Schwartz (197I) reported this same phenomenon in female rats given a diet deficient in $\mathrm{Mg}$. In particular, they noted a considerable fall in the concentration of $\mathrm{Mg}$ and proteins in the milk of rats on the $\mathrm{Mg}$-deficient diet and the rapid exhaustion of these rats during lactation. In our experiments, when the rats were maintained on the Mgdeficient diet during lactation, the rate of gain in weight of their young slowed down even though they had normal weight at birth, fur growth was retarded and their appearance remained sickly. It was not possible to ascertain whether this retardation of growth was the direct result of the $\mathrm{Mg}$ deficiency alone or whether it arose from insufficient nourishment due to the poor quality of the mother's milk. This last possibility appears more likely, for the few animals whose Mg-deficient mothers were given the control diet after parturition had a normal rate of growth.

This experiment makes it possible to state unequivocally that $\mathrm{Mg}$ is an essential element in reproduction. A prolonged deficiency of the mineral led to sterility, and a shorter deficiency of 6 weeks following weaning, though it did not prevent reproduction, nevertheless caused abortions or the resorption of the foetuses.

$\mathrm{Mg}$ appears even more important in lactation. A deficiency in the mineral during this period slowed down the rate of gain in weight in young rats and led to rapid exhaustion of the mothers.

\section{REFERENCES}

Aikawa, J. K. (1960). Proc. Soc. exp. Biol. Med. xo3, 363 .

Andrieux-Domont, C. \& Le Van Hung (1969). C. r. Séanc. Soc. Biol. 163, 1508.

Andrieux-Domont, C. \& Le Van Hung (197 I). Archs Sci. Physiol. 25, 47.

Bodansky, M. \& Duff, V. B. (194I). F. Nutr. 22, 25.

Chein, W. I. \& Kelly, N. (1967). \%. Pharmac. exp. Ther. 156, 150.

Coumel, P. (196r). Gazette Méd. de France 2, 1671.

Doiseau, J. L. (I954). Emploi de l'acetyl methionate de magnesium en obstetrique. Thèse, Paris.

Dumont, M. \& Bernard, P. (r966). Lyon méd. 216, 307.

Friedman, M., Hatcher, G. \& Watson, L. (I967). Lancet i, 703.

Greenwald, J. H., Dubin, A. \& Cardon, L. (1963). Am. F. Med. 35, 854.

Hafez, E. S. E. (1963). J. Anim. Sci. 22, 3 .

Hart, E. B., McCollum, E. V., Steenbock, H. \& Humphrey, G. C. (191 I). Res. Bull. Wis. agric. exp. Stn no. 17. 
Jacquot, R. (1960). Revta Cienc. vet. 55, r2.

Le Breton, E. (1963). In Cancer primitif du foie et des woies biliares. p. 62 [J. Delarue and L. Frünling, editors]. Paris: Masson \& Cie.

Le Roy, J. (1926). C. r. Séanc. Soc. Biol. 94, 431.

L'Estrange, J. L. \& Axford, R. F. E. (1964). J. agric. Sci., Camb. 62, 34 I.

Lowrey, R. S. \& Grunes, D. L. (I968). Proc. Ga Nutr. Conf. Feed Mfrs p. 5 I.

MacIntyre, I. \& Davidsson, D. (1958). Biochem. 7. 70, 456 .

Paunier, L., Radd, I. C. \& Sang Whay Kooh (1968). Pediatrics, Springfield 4r, 385 .

Raoul, Y. \& Marnay, C. (1945). Bull. Soc. Chim. biol. 27, 502.

Salet, J., Polonowski, C., De Gouyon, F., Pean, G., Melekian, B. \& Fournet, J. P. (1966). Archs fr. Pediat. 23, 749 .

Sell, J. L., Cox, A. C. \& Hajj, R. (r966). Int. Congr. Nutr. vir. Hamburg p. 270.

Toverad, K. V. \& Toverad, G. (1931). Acta Pediat., Stockh. Suppl. no. I 1, p. I.

Tufts, E. V. \& Greenberg, D. M. (1937-8). F. biol. Chem. 122, 7 I 5.

Wang, F. L., Wang, R., Khairallah, E. A. \& Schwartz, R. (197I). F. Nutr. ıor, I201. 